\title{
Preliminary Checklist of Spices and Culinary Herbs Sold in Jos, Plateau State, Nigeria.
}

\author{
*Dawang S.N., Affiah D.U., Lanka N.J., Fannap L.M \\ Department of Plant Science and Technology, University of Jos, P.M.B. 2084, Jos, Nigeria.
}

* Author for correspondence:sukatrit@yahoo.com /dawangs@unijos.edu.ng

\begin{abstract}
A survey was undertaken to document the Spices and Culinary herbs that are being sold in markets in Jos, Plateau State. Twenty-one (21) questionnaires were administered to sellers of spices and culinary herbs in seven (7) popular markets in the Jos North and South vicinity. Thirty-seven (37) spices and culinary herbs from Fourteen (14) families were documented. The family that had the highest number of individual representative was Fabaceae. With respect to utilization, the elicited information reveal that the spices and culinary herbs can be used for edible purposes (in cooking food, soups, stew, salads and drinks) or medicinally in the treatment of various ailments. Furthermore, some of the spices and culinary herbs were cultivated within the locality of study while others were purchased from outside the State or the country. Specimens of the spices and culinary herbs were collected and deposited in the herbarium and botanical nursery of the University of Jos, Department of Plant Science and Technology. The checklist and specimens obtained from the current study can serve as a working document for future research on this useful plant group and also in the teaching of economic botany and other related courses.
\end{abstract}

Keywords: Preliminary, Checklist, Spices, Culinary herbs, Jos Plateau State,

\section{Introduction}

Spices and culinary herbs can be categorized as part of economically important plants that are widely used by human beings and a variety of these plants have been listed and discussed in Kaufman (1989) and Kochhar (1998) .In a broad sense, spices have been defined as aromatic vegetable products which are of tropical origin that are used in a pulverized state basically for seasoning, garnishing foods and beverages. These are characterized by pungency, strong odour, and sweet or bitter taste [e.g. hard or hardened parts of pepper, cinnamon, cloves, ginger, turmeric, nutmeg and allspice and vanilla] (Kochhar, 1998).

Kaufman (1989) also describes herbs and spices as aromatic or fragrant products that are used to flavor foods or beverages.

When the aromatic vegetable product is derived or comes from a temperate plant, it is considered to be a culinary herb [e.g. Bay leaves, Coriander, Dill, Fennel, Fenugreek, Mustard seed, Parsley, Sage, Rosemary and Thyme] (Kochhar, 1998). These products were valued in ancient times as basic components of incenses, preservatives for embalming, ointments, perfumes, antidotes against poison, cosmetics and medicines. They were little used in food until in the first century that spices found their way into the kitchen (Kochhar, 1998). Kaufman (1989) also states concerning spices that they are viewed as flavor enhancing plants from the tropics and those from temperate zones as herbs.

Historically, spices have been described as being responsible for the rise and fall of empires and the great sea voyages undertaken to explore distant corners of the globe, as in the search for spices by easily European explorers which led to the discovery of new continent and water ways (Kochhar, 1998).

Kochhar (1998), further states that the utilization and cultivation of spice plants dates back to the beginning of history and most of the spices valued today were known to the ancient civilizations of China, Egypt, Greece, Rome, the East Indies and the rest of the Old World.

In the Country under consideration, various researches on spices and herbs have been conducted and documented. This includes the status assessment of spice Resources in Nigeria revealing a list of some domesticated spices in Nigeria (Olife et al., 2013).Also producers perspective on the medicinal, nutritional and economic potentials of spices in Nigeria (Adebayo et al., 2016) has been investigated and reported. Furthermore a checklist and status of plant species use as spices in Kaduna State of Nigeria have been documented in Kayode and Ogunleye (2008). Green et al. (2012) have reported on Spices and condiments used in the Niger-Delta region of Nigeria their families and ethnobotanical importance. The importance of the plant products being considered is further illustrated by Mann (2011), who has also reviewed the bio potency role of culinary spices and herbs and their chemical constituents in health and commonly used spices in Nigerian dishes and snacks.

The National importance of spices and culinary herbs is further illustrated in use of this food groups by the Nigerian Liquefied Natural Gas Company as its theme for its 2012 yearly calendar. Therein, some selected 
spices and culinary herbs were highlighted alongside their local names, descriptions and uses (NLNG Calendar, 2012).

Furthermore, some Nigerian herbs, spices and condiments their Names descriptions and uses have been outlined (Funke-Koleosho.blogspot.com.ng). To the best of our knowledge, there is a paucity of documented information on spices and culinary spices in the area under study. The survey is therefore aimed at documenting spices and culinary herbs being sold in Jos and environs which can serve as reference material for the teaching of economic botany and on which future research can be based.

\section{Materials And Methods}

The study was carried out in seven (7) selected popular markets within Jos and Bukuru Metropolis (situated in Jos North and South Areas) of Plateau State, Nigeria. Plateau State is one of the States in Nigeria, popularly known as the Home of Peace and Tourism. The State is described as the twelfth largest in the Country and located approximately in the centre of Nigeria(Middle Belt Region). The State is located between latitude $80^{\circ} 24^{\prime} \mathrm{N}$ and longitude $80^{\circ} 32^{\prime}$ and $100^{\circ} 38^{\prime}$ ' east. The State's average temperature ranges are between 18 and $22^{0} \mathrm{C}$, with mean annual rainfall from $131.75 \mathrm{~cm}$ (in the Southern part) to $146 \mathrm{~cm}$ on the Plateau. (Wikipedia, 2016).Agricultural products such as potatoes, groundnut, vegetables of varied sorts, fruits are available in large scale in the State (ngex.com, 2016).

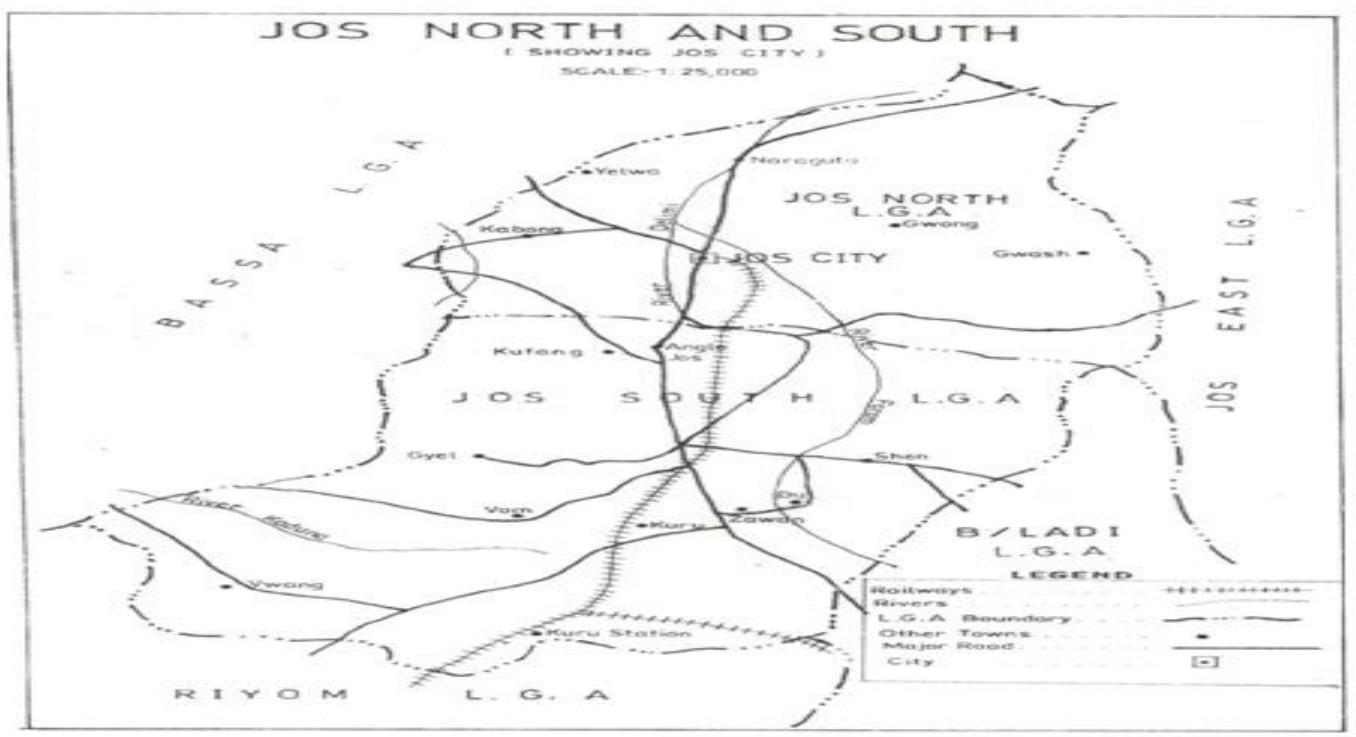

Figure 1: Map of Jos North and South LGA Area of Plateau State

Source: Ministry of Lands and Survey, Plateau State.

For the purpose of the study, data was collected through the administration of questionnaires to twentyone respondents in seven (7) markets within the area studied. At least two questionnaires were administered in each market to sellers of spices and culinary herbs to elicit information on types of spices and culinary herbs sold their uses and place of cultivation or purchase. The markets surveyed are the Chorbe, Farin Gada, Terminus, Vegetable, Building Material, Gyel and Kugiya Markets located within the Jos and Bukuru Metropolis. Common/Local names of the spices and culinary herbs were obtained from the respondents and scientific names and additional local names were obtained from secondary sources. Some specimens of the spices and culinary herbs were also collected and deposited in the Herbarium and Botanical Nursery of the University of Jos Department of Plant Science and Technology.

\section{Results}

Table 1 shows the Personal Bio-data of the Respondents. A higher frequency and percentage of the respondents were of the middle-class age group $9(42.86 \%)$.Gender-wise, most of the respondents were females $12(57.14 \%)$ and with respect to the number of years in the business of selling spices, most of the respondents had an experience of at least up to five years.

Table 1: Personal Bio-Data of Respondents

\begin{tabular}{|l|l|l|l|}
\hline 1 & Age Group & Frequency & Percentage (\%) \\
\hline a. & $18-28$ & 3 & 14.29 \\
\hline b. & $29-39$ & 7 & 33.33 \\
\hline
\end{tabular}


Preliminary Checklist of Spices and Culinary Herbs Sold in Jos, Plateau State, Nigeria.

\begin{tabular}{|l|l|l|l|}
\hline c. & $40-50$ & 9 & 42.86 \\
\hline d. & 51 and above & 2 & 9.52 \\
\hline 2. & Gender & 2 & \multicolumn{2}{l|}{} \\
\hline a. & Male & 9 & 42.86 \\
\hline b. & Female & \multicolumn{2}{|l|}{} \\
\hline 3. & Number of years in business & 57.14 \\
\hline a. & $1-5$ & 10 & 47.62 \\
\hline b. & $6-10$ & 0 & 0 \\
\hline c. & $11-15$ & 4 & 19.05 \\
\hline d. & $15-20$ & 3 & 14.29 \\
\hline e. & $21-25$ & 2 & 9.52 \\
\hline f. & $26-30$ & 2 & 9.52 \\
\hline
\end{tabular}

The Families, Scientific, English and Local names of the spices and culinary herbs sold in the markets surveyed are shown in Table 2. Thirty seven (37) spices and culinary herbs were found to be distributed within fourteen (14) families. Fabaceae had the highest number of seven (7) plants; this is followed by the family Liliaceae which had five (5) plants.

Table 2: Family Scientific, English and Local names of Spices and Culinary herbs sold in the markets surveyed

\begin{tabular}{|c|c|c|c|}
\hline FAMILY & SCIENTIFIC NAME & ENGLISH NAME & LOCAL NAMES \\
\hline \multirow[t]{2}{*}{ ANNONACEAE } & Monodona myristica & $\begin{array}{l}\text { African Nutmeg/ } \\
\text { Calabash nutmeg }\end{array}$ & $\begin{array}{l}\text { Ehuru (Igbo) } \\
\text { Abolakoshe (Yoruba) } \\
\text { Gedanmiya (Hausa) }\end{array}$ \\
\hline & Xylopia aethiopica & Negro Pepper & $\begin{array}{l}\text { Eru (Yoruba) } \\
\text { Kimba (Hausa) } \\
\text { Uda (Igbo) }\end{array}$ \\
\hline \multirow[t]{4}{*}{ APIACEAE } & Anethum graveolens & Dill & \\
\hline & Apium graveolens & Celery & Seleri (Hausa) \\
\hline & Coriandrium sativum & Coriander & \\
\hline & Petroselinum crispum & Parsley & $\begin{array}{l}\text { Faski (Hausa) } \\
\text { Ebolo (Yoruba) }\end{array}$ \\
\hline \multirow[t]{3}{*}{ BRASSICACEAE } & Brassica oleracea & Broccoli & \\
\hline & Brassica oleracea & Cauliflower & $\begin{array}{l}\text { Farin Kabeji (Hausa) } \\
\text { Ori ododoirugbin bi efo (Yoruba) }\end{array}$ \\
\hline & Raphanus sativus & White raddish & \\
\hline EUPHORBIACEAE & Ricinus communis & Castor oil seed & Ogiri Igbo (Igbo) \\
\hline \multirow[t]{7}{*}{ FABACEAE } & Arachis hypogaea & Groundnut paste & Usoji pepper (Igbo) \\
\hline & Trigonella foenum - graecum & Fenugreek & \\
\hline & Moringa oleifera & Moringa leaves & Zogole (Hausa) \\
\hline & Parkia biglobosa & Locust bean & $\begin{array}{l}\text { Okpei (Igbo) } \\
\text { Dawadawa (Hausa) } \\
\text { Iru(Yoruba) }\end{array}$ \\
\hline & Pentaclethra macrophylla & Oil bean seed & Ukpaka (Igbo) \\
\hline & Pentaclethra macrophylla & Local seasoning & Ogiri ugba (Igbo) \\
\hline & Tetrapleura tetraptera & Aidan pod & Uyayak (Efik\& Ibibio) \\
\hline \multirow[t]{3}{*}{ LAMIACEAE } & Mentha rotundifolia & Mint & $\begin{array}{l}\text { Na'aNa'a (Hausa) } \\
\text { Ewe (Yoruba) }\end{array}$ \\
\hline & Ocimum gratissimum & Basil/ Scent leaves & $\begin{array}{l}\text { Ntronk (Efik) } \\
\text { Effirin (Yoruba) } \\
\text { Nchanwu (Igbo) } \\
\text { Daidoya (Hausa) }\end{array}$ \\
\hline & Rosemarianus officinalis & Rosemary & \\
\hline \multirow[t]{2}{*}{ LAURACEAE } & Cinnamoтиm zeylanicum & Cinnamon & Kirfa (Hausa) \\
\hline & Laurus nobilis & Bay leaves & \\
\hline \multirow[t]{5}{*}{ LILIACEAE } & Allium сера & Onions & Albasa (Hausa) \\
\hline & Allium fistulosum & Spring onions & \\
\hline & Allium porrum & Leek onions & Albasa Mai ganye (Hausa) \\
\hline & Allium sativa & Garlic & Tafarnuwa (Hausa) \\
\hline & Allium schoenoprasum & Chives onion & \\
\hline MYRTACEAE & Syzygium aromaticum & Cloves & Kanamfari (Hausa) \\
\hline PIPERACEAE & Piper guineense & Black pepper & $\begin{array}{l}\text { Uziza (Igbo) } \\
\text { Masoro (Hausa) } \\
\text { Iyere (Yoruba) }\end{array}$ \\
\hline RUBIACEAE & Heinsia crinite & Bush apple & Atama (Efik) \\
\hline RUTACEAE & Murraya koenigi & Curry & Korri (Yoruba) \\
\hline \multirow[t]{3}{*}{ SOLANACEAE } & Capsicum аппиит & Sweet pepper & Borkono (Hausa) \\
\hline & & Cherry pepper & Borkono Hausa) \\
\hline & Capsicum frutescens & Chilli pepper & Tatase (Hausa) \\
\hline \multirow[t]{2}{*}{ ZINGIBERACEAE } & Afromonium melegueta & Alligator pepper & Atare (Yoruba) \\
\hline & Curcuma longa & Turmeric & Kurkur (Hausa) \\
\hline
\end{tabular}


Preliminary Checklist of Spices and Culinary Herbs Sold in Jos, Plateau State, Nigeria.

\begin{tabular}{|l|l|l|l|}
\hline & & & Ata ile pupa (Yoruba) \\
\cline { 2 - 4 } & Zingiber officinale & Ginger & Chita \\
\hline
\end{tabular}

The spices and culinary herbs, the parts used and specific uses, elicited from the respondents are shown in table 3. The parts used include the bulb, bud, tuber, pod, leaves and rhizome, seeds, fruit, bark and flower. They also have Edible uses such as being used to cook food and in making soups, stews and salads and drinks. Some of them were also elicited to have medicinal uses for treating various ailments.

Table 3: Spices and Culinary herbs, parts used and their significant elicited uses

\begin{tabular}{|c|c|c|c|c|c|}
\hline $\mathbf{s} / \mathbf{n}$ & $\begin{array}{l}\text { SCIENTIFIC } \\
\text { NAME }\end{array}$ & PARTS USE & USES & & SIGNIFICANT USE \\
\hline 2 & Xylopia aethiopica & Fruit & + & + & $\begin{array}{l}\text { Use in spicing pepper soup } \\
\text { Aids blood circulation }\end{array}$ \\
\hline 3 & Anethum graveolens & Leaves & + & & As stew and Rice spice \\
\hline 5 & Coriandrium sativum & Leaves & + & & Used as rice \& stew spice \\
\hline 6 & Petroselinum crispum & Leaves & + & + & $\begin{array}{l}\text { As rice spice } \\
\text { Use to control Diabetes }\end{array}$ \\
\hline 7 & Brassica oleracea & Leaves \& bud & + & + & $\begin{array}{l}\text { As Jollof rice spice } \\
\text { Use to control Diabetes }\end{array}$ \\
\hline 11 & Arachis hypogaea & Seed & + & & Sauce to eat Egg plant \\
\hline 12 & $\begin{array}{l}\text { Trigonella foenum - } \\
\text { graecum }\end{array}$ & Seed & + & & Powder from seed used in cooking \\
\hline 13 & Moringa oleifera & Leaves & + & + & $\begin{array}{l}\text { For Africa salad and use as Rice } \\
\text { spice }\end{array}$ \\
\hline 14 & Parkia biglobosa & Seeds & + & & As soup spice \\
\hline 15 & $\begin{array}{l}\text { Pentaclethra } \\
\text { macrophylla }\end{array}$ & Seeds & + & & For seeds added to pap \\
\hline 16 & $\begin{array}{l}\text { Pentaclethra } \\
\text { macrophylla }\end{array}$ & Seeds & + & & As soup spice \\
\hline 17 & Tetrapleura tetraptera & Pod & + & + & $\begin{array}{l}\text { As soup spice } \\
\text { Medicinal value }\end{array}$ \\
\hline 18 & Mentha rotundifolia & Leaves & + & + & $\begin{array}{l}\text { Use as Tea, pepper soup \& food } \\
\text { spice } \\
\text { Treatment of Catarrh \& } \\
\text { Hypertension }\end{array}$ \\
\hline 19 & Ocimum gratissimum & Leaves & + & + & $\begin{array}{l}\text { Pepper soup spice } \\
\text { For stomach ache, treatment of } \\
\text { pile \& Typhoid }\end{array}$ \\
\hline 20 & $\begin{array}{l}\text { Rosemarianus } \\
\text { officinalis }\end{array}$ & Leaves & + & & As stew spice \\
\hline 21 & $\begin{array}{l}\text { Cinnamomum } \\
\text { zeylanicum }\end{array}$ & Bark \& leaves & + & & Use in Baking and as food spice \\
\hline 22 & Laurus nobilis & Leaves & + & & Used in flavouring soups and Rice \\
\hline 23 & Allium cepa & Bulb & + & + & $\begin{array}{l}\text { As spice in stew, Rice, Soups, etc. } \\
\& \text { eaten raw } \\
\text { Used in eye treatment }\end{array}$ \\
\hline 24 & Allium fistulosum & Leaves and bulb & + & + & $\begin{array}{l}\text { Used to spice Soups, Rice, Beans, } \\
\text { etc. } \\
\text { Aids in respiratory function, } \\
\text { maintains normal vision and } \\
\text { improves your bone density. }\end{array}$ \\
\hline 25 & Allium porrum & Leaves and bulb & + & & Used in salads, rice spiced \\
\hline 26 & Allium sativa & Bulb & + & + & $\begin{array}{l}\text { Used for cooking } \\
\text { Used in the treatment of cough, } \\
\text { catarrh, fever \& rheumatism }\end{array}$ \\
\hline 27 & $\begin{array}{l}\text { Allium } \\
\text { schoenoprasum }\end{array}$ & Bulb & + & & Used for spicing food \\
\hline 28 & Syzygium aromaticum & Flower \& bud & + & & $\begin{array}{l}\text { Used in meat and salad dressing } \\
\text { Treatment of stomach ache }\end{array}$ \\
\hline
\end{tabular}


Preliminary Checklist of Spices and Culinary Herbs Sold in Jos, Plateau State, Nigeria.

\begin{tabular}{|c|c|c|c|c|c|}
\hline 29 & Piper guineense & Seeds \& leaves & + & + & $\begin{array}{l}\text { Used to spice soup, Kunun African } \\
\text { salad } \\
\text { useful for treating intestinal } \\
\text { diseases, cough, bronchitis and } \\
\text { rheumatism }\end{array}$ \\
\hline 30 & Heinsia crinite & Leaves & + & & Used for cooking soups \\
\hline 31 & Murraya koenigi & Leaves & + & & Used to spice stew and Rice \\
\hline 32 & Capsicum аппиит & Fruit & + & & Peppery spice \\
\hline 33 & Capsicum аппиит & Fruit & + & & Peppery spice \\
\hline 34 & Capsicum frutescens & Fruit & + & & Peppery spice \\
\hline 35 & $\begin{array}{l}\text { Afromonium } \\
\text { melegueta }\end{array}$ & Seeds & + & + & $\begin{array}{l}\text { Eaten raw, used to spice African } \\
\text { salad } \\
\text { Treatment of inflammation \& } \\
\text { sexual dysfunction }\end{array}$ \\
\hline 36 & Curcuma longa & Rhizome & + & & $\begin{array}{l}\text { Used in making juice with carrot, } \\
\text { apple, cucumber \& shaddock }\end{array}$ \\
\hline 37 & Zingiber officinale & Rhizome & + & + & $\begin{array}{l}\text { Used in cooking, tea with lipton. } \\
\text { Smoothing skin }\end{array}$ \\
\hline
\end{tabular}

Table 4: Shows the spices and culinary herbs being sold and their status (cultivated or purchased). Some of them were purchased from areas within and outside the state while others were locally cultivated in Jos. Curcuma longa (Tumeric) is cultivated locally and also purchased from areas outside the state.

Table 4: Spices and Culinary herbs and their status (Cultivated or Purchased)

\begin{tabular}{|c|c|c|c|}
\hline SCIENTIFIC NAME & ENGLISH NAME & $\begin{array}{l}\text { CULTIVATED } \\
\text { OR PURCHASED }\end{array}$ & $\begin{array}{l}\text { PLACE CULTIVATED } \\
\text { PURCHASED }\end{array}$ \\
\hline Monodona myristica & African Nutmeg & Purchased & Enugu \\
\hline Xylopia aethiopica & Negro Pepper & Purchased & Enugu \\
\hline Anethum graveolens & Dill & Cultivated & Jos \\
\hline Apium graveolens & Celery & Cultivated & Jos \\
\hline Coriandrium sativum & Coriander & Cultivated & Jos \\
\hline Petroselinum crispum & Parsley & Cultivated & Jos \\
\hline Brassica oleracea & Broccoli & Cultivated & Jos \\
\hline Brassica oleracea & Cauliflower & Cultivated & Jos \\
\hline Raphanus sativus & White raddish & & \\
\hline Ricinus communis & Castor oil seed & Purchased & Enugu, Abia \\
\hline Arachis hypogaea & Groundnut paste & Cultivated & Jos \\
\hline Trigonella foenum-graecum & Fenugreek & Purchased & Niger, Sudan \\
\hline Moringa oleifera & Moringa leaves & Cultivated & Jos \\
\hline Parkia biglobosa & Locust bean & Purchased & Jos, Enugu \\
\hline Pentaclethra macrophylla & Oil bean seed & Purchased & Enugu, Abia \\
\hline Pentaclethra macrophylla & Local seasoning & Purchased & Enugu, Abia \\
\hline Tetrapleura tetraptera & Aidan pod & Purchased & Akwa Ibom \\
\hline Mentha $X$ rotundifolia & Mint & Cultivated & Jos \\
\hline Ocimum gratissimum & Basil/ Scent leaves & Cultivated & Jos \\
\hline Rosemarianus officinalis & Rosemary & Cultivated & Jos \\
\hline Cinnamoтum zeylanicum & Cinnamon & Purchased & Guinea \\
\hline Laurus nobilis & Bay leaves & Purchased & Delta \\
\hline Allium cepa & Onions & Purchased & Kano, Sokoto, Jigawa \\
\hline Allium fistulosum & Spring onions & Cultivated & Jos \\
\hline Allium porrum & Leek onions & Cultivated & Jos \\
\hline Allium sativa & Garlic & Purchased & Jos, Sokoto, Kano \\
\hline Allium schoenoprasum & Chives onion & Purchased & Jos \\
\hline Syzygium aromaticum & Cloves & Purchased & Jos \\
\hline Piper guineense & Black pepper & Purchased & Enugu, Abia \\
\hline Heinsia crinite & Bush apple & Purchased & Akwa Ibom \\
\hline Murraya koenigi & Curry & Cultivated & Jos \\
\hline \multirow[t]{2}{*}{ Capsicum aпnиит } & Sweet pepper & Cultivated & Jos \\
\hline & Cherry pepper & Cultivated & Jos \\
\hline Capsicum frutescens & Chilli pepper & Cultivated & Jos \\
\hline Afromonium melegueta & Alligator pepper & Purchased & Enugu, Abia \\
\hline Curcuma longa & Turmeric & $\begin{array}{l}\text { Cultivated } \\
\text { Purchased }\end{array}$ & Jos, Bauchi, Maiduguri \\
\hline Zingiber officinale & Ginger & Purchased & Kaduna \\
\hline
\end{tabular}

\section{Discussion}

The high number of thirty-seven (37) spice and culinary herbs obtained in this study is possibly a strong indication of the need and high utilization of these plants by various users of these plant products, which can be tagged as economically important, Kaufman (1989) and Kochhar (1998). The family Fabaceae had the 
highest number of individuals of seven plants. Its representative members include Arachis hypogaea (Groundnut paste),Trigonella foenum-graecum (Fenugreek), Moringa oleifera (Moringa),Parkia biglobosa (Locust Bean),Pentaclethra macrophylla (Oil Bean Seed),Pentaclethra macrophyla ( Local seasoning- Ogiri Ugba (Igbo)) and Tetrapleura tetraptera (Aidan pod). This possibly reflects the importance of this family with quantities which make them suitable for use as condiments and flavourings. Some of these have also been reported as useful Nigerian spices (Funke-Koleosho.blogspot.com.ng, Mann (2011) and NLNG Calendar (2012) Many of the spices and culinary herbs had local names which is a high indication of a widespread indigenous acceptance and utilization.

All the spices and culinary herbs obtained in the study have edible uses various application in cooking soups,stews,making salads and drinks due to their effect in food synergy, flavor enhancer, visual, convenience in everyday cooking and olfactory stimulation in making food attractive (Mann 2011). A few of them have elicited medicinal applications in treating ailments such as Hypertension(Mint-Mentha rotundifolia,CeleryApium graveolens), Diabetes (Celery-Apium graveolens,Parsley-Petroselinum crispum ,Broccoli-Brassica oleracea) catarrh (Mint-Mentha rotundifolia,Garlic-Allium sativa) stomach (Cloves-Syzygium aromaticum,Basil- Ocimum basilicum), pile (Basil- Ocimum basilicum.Futhermore, Basil- Ocimum basilicum is used in the treatment of typhoid, Garlic-Allium sativa is used to treat fever, Piper guineese is used in treating rheumatism, intestinal diseases, cough and bronchitis, while Alligator pepper (Afromonium melegueta) is utilized in the treatment of inflammation and sexual dysfunction.

Some other spices such as 'Oburunbebe','Kula' and 'Pasakori' were also documented during the survey (though botanical names of these had not been obtained as of the time of reporting this research).

Onions (Allium cepa) and Spring Onions (Allium fistolum) are also used in eye treatment, including maintaining normal vision, aiding respiratory function and improving bone density. Ginger (Zingiber officinale) used is smoothing skin and Negro Pepper (Xylopia aethiopica) in aiding blood circulation. Mann (2011) has further outlined the use of spices as a result of their pharmacological aspects, antioxidant capacity, and antimicrobial activity. The medicinal and other aspects of some of the documented spices and culinary herbs such as Garlic, Celery, Cayenne, Cinnamon, Tumeric, Cloves, Basil, Rosemary and Ginger have been discussed ( Chevallier ,2000). This indicates the possibility of these plant products to be used as herbal remedies as the elicited uses are put into scientifically test. Adebayo et al., (2016) have also reported many of the spices and culinary herbs documented in this study as economically, nutritionally and medicinally important in Nigeria. Possibly due to the demand for these plant products, many of them are locally cultivated while quite numbers are purchased from outside the State of Plateau and even Nigeria. The various exotic culinary herbs that are conveniently grown in the State is a high indication that Plateau State possesses good prospects of large scale production of various culinary herbs. This is worth pursuing in the current bid to diversify the economy of the State.

\section{Conclusion}

This survey has revealed the diversity of spices and culinary herbs sold in Jos, alongside some significant uses, local names, their status whether they are cultivated a purchased. The checklist and specimens provided can henceforth serve as reference material for further research on spices and culinary herbs and also for teaching of Economic Botany and related courses.

\section{References}

[1]. Adebayo, O.S., Akinpelu, C.A., Fariyike, T.A., and O. Olajide-Taiwo Lawrence (2016). Producer's perspective on the Medicinal, Nutritional and Economic Potentials of spices in Nigeria. Journal of Biological and Chemical Research 33(1):206-213

[2]. Andrew, (2000). Encyclopedia of Herbal Medicine Second America edition 2000 Inc., Darling Kindersley, New York.

[3]. Funke-Koleosho.blogspot.com.ng

[4]. Green B.O., Nworgu F.C. and Obazee M.N. (2012). Spices and food condiments in Niger-Delta region of Nigeria. African Journal of Biotechnology 11(79):14468-14473

[5]. Kaufman, P.B., Carlson, T.F., Dayanan, D.P., Evans, M.L., Fisher, J.B., Parks, C., and Wells, J.R. (1989). Plants: Their Biology and Importance. Harper and Row Publishers, New York. Pp 757

[6]. Kayode, J. and Ogunleye, T.O. (2008). Checklist and status of plant species used as spices in Kaduna State of Nigeria. African Journal of General Agriculture 4(1):13-18

[7]. Kochhar, S.L. (1998). Economic Botany in the Tropics. $2^{\text {nd }}$ Edition. Macmillan, India Ltd. Pp 604

[8]. Mann, A. (2011). Biopotency role of culinary spices and herbs and their constituents in health and commonly used spices in Nigerian dishes and snacks. African Journal of Food Science 5(3):111-124

[9]. NLNG Calendar, (2012). Nigerian Liquefied Natural Gas Company, 2012 Calendar.

[10]. Ngex.com/Nigeria/places/states/plateau.htm (Retrieved 05/07/2016)

[11]. Olife, I.C., Onwualu, A.P., Uchegbu, K.I., and Jolaoso, M.A. (2013). Status assessment of spice resources in Nigeria. Journal of Biology, Agriculture and Healthcare 3(9):12-19

[12]. Wikipedia (2016).http://en.wikipedia.org/wiki/Plateau_State. (Retrieved 30/05/2016). 